\title{
Production of Biochar from Date Palm Fronds and its Effects on Soil Properties
}

\author{
Mohamed A. Badawi \\ Soils, Water and Environment Research Institute, ARC, Egypt and General Manager, Emirates \\ Biofertilizers Factory, UAE \\ dr_badawi22@hotmail.com
}

Keywords: biochar, date palm wastes, soil conditioning

\begin{abstract}
The UAE has the largest number of date palm trees in the Arab world, there are about 42 million date palm trees. Each tree generates about 15 kilograms (kg) of waste biomass annually, totaling 600 million $\mathrm{kg}$ of green waste. Converting date palm waste into biochar can reduce carbon dioxide $\left(\mathrm{CO}_{2}\right)$ and methane $\left(\mathrm{CH}_{4}\right)$ emissions generated by the natural decomposition or through burning of the waste. Biomass produced from date palm trees can't be composted easily in normal composting process due to its high content of lignocellulose compound, while the biochar production can be the option to generate both energy and soil conditioner for the improvement of sandy soil under the gulf countries severe climate. Biochar is one of the most stable biologically produced carbon sources that can be added to soil. It processes agricultural waste into a soil enhancer that improves soil fertility, saves water, helps to mitigate greenhouse gas (GHG) emissions and fight global warming. The United Arab Emirates has sandy soil with very low water and nutrient holding capacities, using biochar improved its soil WHC, and biological activities. In this paper we did several trials to evaluate the produced biochar from date palm tree green wastes as a soil conditioner in sandy soil. Research has been undertaken in a pilot plant of 200 -liter capacity. The produced biochar $(25 \% \mathrm{w} / \mathrm{w})$ of raw materials was used as a soil conditioner for sandy soil. The soil physical, chemical and biological properties were tested in pot experiment with different mixing ratios and the results showed better improvements in its properties. The aim of this study was to evaluate the effect of biochar and organic soil amendments on soil physicochemical and microbial load, carbon sequestration potential.
\end{abstract}

\section{Introduction}

The topic of utilizing agricultural or forestry waste as co-products such as biochar has received great interest from the scientific community.

Around the world, there are growing initiatives on finding strategies to encourage collection of agricultural waste as new products in a logical and economical way to be used in other applications rather than disposal in landfill.

Date palm trees in the UAE generate around 600000 tons of date fronds which is an abundantly available agricultural waste and small percentage is economicaly used and recycled as well as in many date producing countries. Date trees are cultivated in arid and semi-arid regions and can thrive in long and hot summers, low rainfall and very low relative humidity [1]. About 105 million trees are available around the world covering over a million hectares. UAE is one of the largest producers of date fruits with more than 42 million date palm trees and an annual production rate of 770,000 tons of date fruits [2].

The United Arab Emirates (UAE) has sandy soil with very low water and nutrient holding capacities. 
In these conditions, date palm is considered one of the most resilient crops in the region.

Over the years, with rising temperatures and scarce precipitation, there have been calls for new ways to conserve water, improve soil properties and prevent nutrient loss to achieve future food and nutrition security.

Biochar is a solid product produced from thermal conversion of unstable carbon-enriched materials into stable carbon-enrichedcharred materials that can be incorporated into the soils as a mean for agronomic or environmental management.

Biochar can be produced out of a long list of feedstock. Some of this raw materials can be agricultural waste (wheat straw, nuts and coconuts shells, waste wood, etc.) biomass energy crops (corn, cereals, wood pellets, palm oil, oilseed rape), bioenergy residues, compost (green waste), animal manure (camel, chicken...), sewage sludge, etc [3].

The composition of biochar (content in carbon, nitrogen, potassium, calcium, etc) is directly related on the feedstock used and the duration and temperature of pyrolysis.

At higher temperatures, biochar showed high particle density, high porosity but the bulk density showed small differences between varying temperatures as shown in Table (1). However, [4] stated that increasing pyrolysis temperatures produced high bulk density and an increase of porosity for rice husk and empty fruit bunch biochars.

During the pyrolysis process, biomass porosity increased with increasing pyrolysis temperature.

This can be attributed to volatilization processes and the loss of organic compounds, which creates more voids [5]. And found that particle density of wood derived biochar increased from $1344 \mathrm{~kg} / \mathrm{m} 3$ to $1742 \mathrm{~kg} / \mathrm{m} 3$ with an increase of pyrolysis temperature from $300{ }^{\circ} \mathrm{C}$ to $700{ }^{\circ} \mathrm{C}$. [6] also reported that the solid density of biochar prepared from sewage sludge increased with increasing pyrolysis temperature while the bulk density decreased, as a result; the porosity increased.

In 2012, the International Biochar Initiative defines biochar as 'solid material obtained from thermochemical conversion of biomass in an oxygen limited environment [7]. Pyrolysis is an industrialized thermochemical conversion process of biomass into biochar, syngas and bio-oil . The yield of end products depends upon the temperature elevated in the pyrolysis.

Biochar has been produced with a range of $\mathrm{pH}$ values between 4 and 12, dependent upon the feedstock and pyrolysis temperature[8].

Generally, low pyrolysis temperatures $\left(<400^{\circ} \mathrm{C}\right)$ yield acidic biochar, while increasing pyrolysis temperatures produce alkaline biochar.

Once incorporated to the soil, surface oxidation occurs due to reactions of water, $\mathrm{O}_{2}$ and various soil agents $[8,9]$. The cation exchange capacity (CEC) of fresh biochar is typically very low, but increases with time as the biochar ages in the presence of $\mathrm{O}_{2}$ and water $[8,10,11]$.

Biochar is used as a soil amendment to improve soil nutrient status, $\mathrm{C}$ storage and/or filtration of percolating soil water [12]. Biochar from pyrolysis and charcoal produced through natural burning share key characteristics including long residence time in soils and a soil conditioning effect [13]. Research has claimed that application of biochar can increase soil organic carbon (SOC), improve the supply of nutrients to plants and therefor enhance plant growth and soil's physical, chemical, and biological properties [13,14].

Biochar can alter soil physical properties such as structure, pore size distribution and density, with implications for soil aeration, water holding capacity, plant growth, and soil workability. Consequently this may improve soil water and nutrient retention [15].

Biochar may increase the overall net soil surface area [16]; reduce soil bulk density which is generally desirable for most plant growth [17]. 
Biochar has a higher surface area and greater porosity relative to other types of soil organic matter, and can therefore improve soil texture and aggregation, which improves water retention in soil. Improved water holding capacity with biochar additions is most commonly observed in coarse-textured or sandy soils $[13,18]$.

Biochar has a higher sorption affinity for a range of organic and inorganic compounds, and higher nutrient retention ability compared to other forms of soil organic matter [20,21] and [2224].

Previous analysis have shown that it is feasible to prepare biochar with relatively high BET surface areas from date palm fronds, which is favorable for microbial communities to grow and therefore enhancing fertility of the soils,. Biochar enhances soils. By converting agricultural waste into a powerful soil enhancer that holds carbon and makes soils more fertile, we can boost food security, discourage deforestation and preserve cropland diversity [25].

Biochar addition may increase soil microbial biomass (population size), and affect microbial community structure (species present) and enzyme activities.

Australian researchers observed an increase in microbial biomass in the presence of poultry litter biochar in a hard-setting soil growing radishes. While increased microbial biomass has been observed, it has often been accompanied by a reduction in microbial activity, most probably due to sorption of labile organics, nutrients, and enzymes on the biochar.

Biochar application has been shown to increase the rate of mycorrhizal fungal colonization in roots, although it depends on the biochar, soil type and plant species.

There is growing evidence that biochar addition can reduce disease severity for several crop species [26-29].

\section{Materials and methods}

\section{Biochar preparation}

A-Bench scale biochar preparation: Thermal decomposition of the biomass was carried out using a bench-scale slow pyrolysis process in an oxygen deprived condition to convert the date fronds, biomass into stable biochar. For each experiment, about $100 \mathrm{~g}$ of dry biomass sample were placed in a ceramic dish and purged with nitrogen gas to provide a low-oxygen environment.

The container was covered with aluminium foil with two small vents allowing only the evolved volatiles to escape.

The biomass was pyrolysed inside a muffle furnace. In this study, the evolved volatile was not collected or quantified.

The pyrolysis temperature was increased to four terminal temperature levels (350, 450, 550 and $650{ }^{\circ} \mathrm{C}$ ) and kept constant for a residence time of $2 \mathrm{~h}$.

The biochar was cooled in the furnace to room temperature and then placed inside a desiccator for $15 \mathrm{~min}$.

The mass yield was obtained from the final weight of the biochar. The produced biochars are named as BC 1, BC-2, BC 3, and BC4, where BC and numbers denoting biochar and pyrolysis temperatures, respectively.

Sandy soil was collected from Emirates bio farm, analysis is in table 1). Date palm tree waste leaves, was collected from al Ain City, UAE. The waste was dried in air under sunshine and then chopped to small pieces. Pyrolysis of the processed date palm waste was carried out in a closed stainless steel container, at $350{ }^{0} \mathrm{C}$ were maintained for $4 \mathrm{~h}$ under a limited supply of air.

Feedstock samples were pyrolyzed to the desired temperature at the rate of $5{ }^{\circ} \mathrm{C} \mathrm{min}-1$.

The biochars produced were left to cool inside the furnace overnight. 
Characterization is an essential step to evaluate the physicochemical properties of biomass prior to the pyrolysis process.

The biomass characterization was carried out by using proximate and ultimate analysis on dry matter. Proximate analysis included the measurements of moisture content, ash content, volatile matter and fixed carbon.

The moisture content was determined by measuring the loss in mass at $105{ }^{\circ} \mathrm{C}$ for $24 \mathrm{~h}$. The volatile matter content was measured by placing dry biomass inside a muffle furnace at $550{ }^{\circ} \mathrm{C}$ for $6 \mathrm{~h}$ to measure mass loss due to volatilization of volatile components Black et al. [30].

Bulk density was determined according to Mudoga et al., (2008) method by filling a 10- ml tube with dry adsorbent.

The tubes were capped, tamped to reach a constant volume by tapping on a table, and weighed. Whereases, particle density was determined by using the method of volume displacement according to Khanmohammadi et al., (2015) by using water instead of kerosene. The $\mathrm{pH}$ of the biomass was measured by adding $1 \mathrm{~g}$ of powdered biomass to $20 \mathrm{~mL}$ of deionized water (1:20) and heated to $90 \mathrm{oC}$ with continuous stirring for $20 \mathrm{~min}$ and was subsequently determined by using a pH meter. Soils: Soil physical and chemical analysis were done according to [30].

Electrical conductivity (EC) and $\mathrm{pH}$ were determined potentiometrically on a 1:2 soil massto-water volume paste, Effect of biochar on sandy soil properties was carried out in $5 \mathrm{~kg}$ pots and three replicates from each. Treatments include control, 1ton per hectare, two tons per hectare, three tons per hectare and 4 tons per hectare was evaluated for 180 days.

Irrigation was performed on schedule to maintain the moisture content in the soil. Pots were incubated at $28^{\circ} \mathrm{C}$ in the green house, Periodical samples were taken after one week, 30 days, 60 days, 90 days and at the end of experiment at 180 days.

Soil samples were preapared and tested according to protocol followed by [30]

Table 1 criterial of materials used.

\begin{tabular}{lcc}
\hline Materials & Sandy soil & Biochar \\
\hline Water Holding Capacity, \% & 32.0 & 150.0 \\
\hline Cation Exchange Capacity & 7.6 & 48.2 \\
\hline Organic matter & 0.22 & 75.0 \\
\hline Organic carbon & 0.12 & 43.6 \\
\hline Total nitrogen & 0.12 & 1.12 \\
\hline C/N & --- & 38.9 \\
\hline pH & 8.9 & 6.8 \\
\hline EC Ms/d & 5.1 & 6.4 \\
\hline
\end{tabular}

Total bacterial counts CFU, was measured using nutrient agar media, according to [31-32], while potato dextrose media was used to measure the total fungi in respective order, according to [32].

\section{Results and discussion}

Table (2) depicts the effects of pyrolysis temperature on mass yield, Biochar bulk density and $\mathrm{pH}$ of the biochar were also studied.

The biochar was prepared by using a slow pyrolysis process under different temperatures (350, 450, 550 and $650{ }^{\circ} \mathrm{C}$ ) for $2 \mathrm{~h}$. The results of the analysis indicated that the biochar bulk density were affected by the pyrolysis temperature, and it decreased with increasing pyrolysis 
temperature e.g. from $0.53,0.49,0.48$, and $0.47 \mathrm{~g} / \mathrm{l}$.. The biochar mass yield was inversely proportional to the pyrolysis temperature.

The mass yields were $41.0 \%, 31.8 \%, 26.9 \%$ and $22.6 \%$ at temperatures (350, 450, 550 and $650{ }^{\circ} \mathrm{C}$ ), respectively The $\mathrm{pH}$ of the biochar increased with the pyrolysis temperature, while the bulk density decreased. Therefore, the biochar prepared from date seed had a highly porous structure and thus it is expected to improve soil physical, chemical and biological properties [3234].

Table 2 Effect of temperature variations on biochar quality.

\begin{tabular}{lcccc}
\hline Treatment & $\begin{array}{c}\text { Temperature } \\
\left.\mathbf{(}^{\mathbf{0}} \mathbf{C}\right)\end{array}$ & $\begin{array}{c}\text { Biochar yield } \\
\mathbf{( \% )}\end{array}$ & $\begin{array}{c}\text { Bulck density } \\
\mathbf{g} / \mathbf{l}\end{array}$ & $\mathbf{p H}$ \\
\hline BC 1 & 350 & 41.0 & 0.532 & 6.8 \\
\hline BC 2 & 450 & 31.8 & 0.498 & 7.2 \\
\hline BC 3 & 550 & 26.9 & 0.487 & 8.0 \\
\hline BC 4 & 650 & 22.6 & 0.471 & 8.9 \\
\hline
\end{tabular}

The $\mathrm{pH}$ values of the biochar is shown in table 2. The values increased with the pyrolysis temperature ranged from 6.8 to 8.9. These results were similar to other literature values that indicate most of derived biochar are alkaline[33,37]. [37] found that the $\mathrm{pH}$ values of biochars derived from wheat straw, wood, spruce and needle mixture ranged from 6.9 to 9.2, which indicates a certain liming effect that may be achieved after biochar application.

The findings of [33] indicated that rice husk and empty fruit bunch derived biochars produced at $300^{\circ} \mathrm{C}$ have acidic nature but that those produced at $650^{\circ} \mathrm{C}$ were alkaline. [38] stated that biochar produced from canola straw, corn straw, peanut and soybean straws at different pyrolysis temperatures had shown the alkalinity nature and $\mathrm{pH}$ of biochars increased with the pyrolysis temperature.

Table 3 Periodical changes of organic carbon content in sandy soil amended with biochar through 180 days.

\begin{tabular}{lcccc}
\hline Treatment & Zero time & 60 Days & 120 Days & $\mathbf{1 8 0}$ days \\
\hline Control & 0.14 & 0.13 & 0.13 & 0.09 \\
\hline $\begin{array}{l}\text { Sandy soil }+ \\
\text { 1\% biochar }\end{array}$ & 0.20 & 0.18 & 0.17 & 0.17 \\
\hline $\begin{array}{l}\text { Sandy soil }+ \\
\mathbf{2 \%} \text { biochar }\end{array}$ & 0.27 & 0.25 & 0,24 & 0.24 \\
\hline $\begin{array}{l}\text { Sandy soil + } \\
\mathbf{3 \%} \text { biochar }\end{array}$ & 0.35 & 0.34 & 0.33 & 0.31 \\
\hline $\begin{array}{l}\text { Sandy soil }+ \\
\mathbf{4 \%} \text { biochar }\end{array}$ & 0.42 & 0.40 & 0.39 & 0.38 \\
\hline
\end{tabular}

In table (3). It is very clear that treatments recived biochar improved its organic matter content compared to control and increased with increasing biochar content from $1 \%$ to $4 \%$ reaching $0.42 \%$ organic carbon compared to 0.14 in the control. During the incubation time it showed big loss in the control treatment while organic carbon loss from treated soil was minimum. And this is mainly because carbon is very low release carbon, and this won't lead to carbon sequestration. 
Table 4 Periodical changes of Water holding capacity in sandy soil amended with biochar through 180 days.

\begin{tabular}{lcccc}
\hline Treatment & Zero time & 60 Days & 120 Days & 180 days \\
\hline Control & 17.6 & 16.0 & 16.5 & 16.1 \\
\hline $\begin{array}{l}\text { Sandy soil }+ \\
\text { 1\% biochar }\end{array}$ & 21.2 & 21.0 & 20.7 & 20.5 \\
\hline $\begin{array}{l}\text { Sandy soil }+ \\
\text { \%\% biochar }\end{array}$ & 26.5 & 26.7 & 26.0 & 25.3 \\
\hline $\begin{array}{l}\text { Sandy soil }+ \\
\text { \%\% biochar }\end{array}$ & 28.1 & 27.8 & 26.9 & 26.8 \\
\hline $\begin{array}{l}\text { Sandy soil }+ \\
\text { 4\% biochar }\end{array}$ & 33.7 & 33.0 & 31.9 & 31.7 \\
\hline
\end{tabular}

Table (4) depicted the water holding capacity of soil treated with biochar in comparison to control.

All treatments received biochar showed water holding capacity improvement compared to control and increasing biochar content increased water holding content values [37-39].

Table 5 Periodical changes of Total Plate Counts, TPC content in sandy soil amended with biochar through 180 days, CFU/10 6 .

\begin{tabular}{lllll}
\hline Treatment & 7 Days & 60 Days & 120 Days & 180 days \\
\hline Control & 37.0 & 34.0 & 36.0 & 32.0 \\
& & & & \\
\hline Sandy soil + 1\% biochar & 68.0 & 67.2 & 88.1 & 74.3 \\
\hline Sandy soil + 2\% biochar & 84.0 & 88.0 & 92.3 & 89.0 \\
\hline Sandy soil + 3\% biochar & 87.0 & 96.5 & 98.1 & 99.4 \\
\hline Sandy soil + 4\% biochar & 98.7 & 103.0 & 107.0 & 107.8 \\
\hline
\end{tabular}

Table 6 Periodical changes of Total fungi colonies content in sandy soil amended with biochar through 180 days, CFU/10 4 .

\begin{tabular}{lllll}
\hline Treatment & 7 Days & $\mathbf{6 0}$ Days & 120 Days & $\mathbf{1 8 0}$ days \\
\hline Control & 7.20 & 7.29 & 7.31 & 7.28 \\
& & & & \\
\hline Sandy soil + 1\% biochar & 12.10 & 12.90 & 13.20 & 13.90 \\
\hline Sandy soil + 2\% biochar & 14.30 & 16.10 & 17.20 & 17.00 \\
\hline Sandy soil + 3\% biochar & 16.00 & 17.40 & 18.60 & 19.00 \\
\hline Sandy soil + 4\% biochar & 18.30 & 19.20 & 19.40 & 22.00 \\
\hline
\end{tabular}

Table 5 and 6 describe the total bacterial population and total fungi population measured by plate count technique in the soil amended with different rates of biochar from $1 \%$ till $4 \%$. Numbers of CFU increased with increasing dose of biochar applied in all treatments. All treatments showed high microbial counts over control. 
Bacterial population was in the range of 32-37 milions bacteria in the control treatment while increased sharply in all treatments reaching 107 millions micrope after 180 days.

Fungi population showed less numbers, e.g. control treatments showed $7 \mathrm{X} 10^{4}$, while for treatments received biochar, the fungi numbers grown in the range of 12-22 millions $\mathrm{X} 10^{4}$. The significant differences in bacteria, and fungi population were observed between biochar and control [40-42].

\section{Conclusion}

BIOCHAR is an organic soil amendment which is rich in organic carbon. A significant percent of the organic carbon is recalcitrant in nature. Recalcitrant organic carbon does not decompose easily in soil \& keeps performing long after soil application. This ensures long term soil fertility unlike synthetic chemical fertilizers \& other organic soil conditioners that only provide short term benefits. Chemical fertilizers \& other organic soil conditioners have to be replenished regularly to ensure effectiveness. Biochar addition may increase soil microbial biomass (population size), and affect microbial community structure (species present) and enzyme activities.

\section{Refrences}

[1] T. Ahmad, M, Danish, M. Rafatullah, A. Ghazali, O. Sulaiman, R. Hashim, M.N.M. Ibrahim, The use of date palm as a potential adsorbent for wastewater treatment: a review, Environ Sci Pollut Res Int, 19(5), 1464-1484. DOI: 10.1007/s11356-011-0709-8 (2012). https://doi.org/10.1007/s11356-011-0709-8

[2] FAO (Food and Agriculture Organization of the United Nations), Statistical Databases (2012).

[3] S.P. Sohi, E. Krull, E. Lopez-Capel, R. Bol., A review of biochar and its use and function in soil, Advances in Agronomy, San Diego, Elsevier Academic Press Inc. 105 (2010) 47-82. https://doi.org/10.1016/s0065-2113(10)05002-9

[4] N. Claoston, A.W. Samsuri, M.H. Ahmad Husni, M.S. Mohd Amran, Effects of pyrolysis temperature on the physicochemical properties of empty fruit bunch and rice husk biochars. Waste Manag Res, 32(4), 331-339, 2014. https://doi.org/10.1177/0734242x14525822

[5] C.E. Brewer, K. Schmidt-Rohr, J.A. Satrio, R.C. Brown, Characterization of biochar from fast pyrolysis and gasification systems. Environ. Prog. Sustain. Energy 28 (2014) 386-396. https://doi.org/10.1002/ep.10378

[6] Z. Khanmohammadi, M. Afyuni, M.R. Mosaddeghi, Effect of pyrolysis temperature on chemical and physical properties of sewage sludge biochar. Waste Management \& Research 333 (2015) 275-283. https://doi.org/10.1177/0734242x14565210

[7] D.R. Kasten, J. Heiskanen, K. Englund, A., Tervahauta, Pelleted biochar: Chemical and physical properties show potential use as a substrate in container nurseries. Biomass and Bioenergy, 35-5 (2012) 2018-2027. https://doi.org/10.1016/j.biombioe.2011.01.053

[8] J. Lehmann, A Handful of Carbon. Nature 447-7141 (2007) 143-144.

https://doi.org/10.1038/447143a 
[9] C.H. Cheng, J. Lehmann, J.E. Thies, S.D. Burton, M.H. Engelhard, Oxidation of black carbon by biotic and abiotic processes, Organic Geochemistry 37 (2006) 1477-1488. https://doi.org/10.1016/j.orggeochem.2006.06.022

[10] C.H. Cheng, J. Lehmann, M. H. Engelhard, Natural oxidation of black carbon in soils: Changes in molecular form and surface charge along a climosequence. Geochim.Cosmochim. Acta 72 (2008) 1598-1610. https://doi.org/10.1016/j.gca.2008.01.010

[11] B. Liang, J. Lehmann, D. Solomon, J. Kinyangi, J. Grossman, B. O’Neill, J.O. Skjemstad, J. Thies, F.J. Luizao, J. Petersen. E.G. Neves, Black carbon increases cation exchange capacity in soils. Soil Science Society America Journal, 70 (2006) 1719-1730. https://doi.org/10.2136/sssaj2005.0383

[12] J. Lehmann, S. Joseph, Biochar for Environmental Management: Science and Technology. Earthscan, London \& Sterling, VA. (2009) 416.

[13] B. Glaser, J. Lehmann, W. Zech, Ameliorating physical and chemical properties of highly weathered soils in the tropics with charcoal - a review Biology and Fertility of Soils 35 (2002) 219-230. https://doi.org/10.1007/s00374-002-0466-4

[14] M.A. Rondon, J. Lehmann, J. Ramirez, M. Hurtado, Biological nitrogen fixation by common beans (Phaseolus vulgaris L.) increases with bio-char additions, Biology and fertility of soils 43 (2007) 699-708. https://doi.org/10.1007/s00374-006-0152-z

[15] A. Downie, A. Crosky P. Munroe, Physical properties of biochar. In Biochar for environmental management: science and technology Eds. J. Lehmann and S. Joseph. Earthscan, London; Sterling, VA (2009) 13-32.

[16] K.Y. Chan, L. Van Zwieten, I. Meszaros, A. Downie, S. Joseph, Agronomic values of greenwaste biochar as a soil amendment, Australian Journal of Soil Research, 45-8 (2007) 629634. https://doi.org/10.1071/sr07109

[17] K. Chan , Z. Xu, Biochar: Nutrient Properties and Their Enhancement. In Biochar for Environmental Management: Science and Technology (Eds J Lehmann and S Joseph), Earthscan: London, UK (2009)53-66.

[18] J.W. Gaskin, K.C. Das, A.S. Tassistro, L. Sonon, K. Harris, B. Hawkins, Characterization of char for agricultural use in the soils of the southeastern United States, in: W.I. Woods (Ed.), Amazonian Dark Earths: Wim Sombroek’s Vision\|, Springer Science, Business Media, Heidelberg, Germany, (2009) 433-443. https://doi.org/10.1007/978-1-4020-9031-8_25

[19] N.C. Brady, R.R. Weil, he nature and properties of soils, Macmillan: New York, 2014.

[20] T.D. Bucheli, O. Gustafsson, Quantification of the soot-water distribution coefficient of PAHs provides mechanistic basis for enhanced sorption observations Environ. Sci.Technol 34 (2000) 5144-5151. https://doi.org/10.1021/es000092s

[21] T.D. Bucheli, O. Gustafsson, Soot sorption of non-ortho and ortho substituted PCBs, Chemosphere (2003) 53:515-522. https://doi.org/10.1016/s0045-6535(03)00508-3

[22] R.M. Allen-King, P. Grathwohl, , W.P. Ball, New modeling paradigms for the sorption of hydrophobic organic chemicals to heterogeneous carbonaceous matter in soils, sediments, and 
rocks. Advances in Water Resources 25 (2002) 985-1016. https://doi.org/10.1016/s03091708(02)00045-3

[23] S. Kleineidam, C. Schuth, P.Grathwohl, Solubilitynormalized combined adsorptionpartitioning sorption isotherms for organic pollutants. Environ. Sci. Technol. 21 (2002) 46894697. https://doi.org/10.1021/es010293b

[24] B.T. Nguyen, J. Lehmann, J. Kinyangi, R. Smernik, S.J. Riha, M.H. Engelhard, Long-term black carbon dynamics in cultivated soil. Biogeochemistry 89 (2008) 295- 308. https://doi.org/10.1007/s10533-008-9220-9

[25] T.A. Muhamed, B. Lopez, C.G. Lina J.E. Shmidt, Economic analysis of biochar production from date palm fronds. I Energy, MASDAR institute of science and technology, PO Box 54224, AD, UAE, 2018.

[26] J. Lehmann, M.C. Rillig, J. Thies, C.A. Masiello, W.C. Hockaday, D. Crowley, Biochar effects on soil biota—a review, Soil Biol. Biochem. 43 (2011) 1812-1836.

https://doi.org/10.1016/j.soilbio.2011.04.022

[27] J. Lehmann, J. Gaunt, M. Rondon, Bio-char sequestration in terrestrial ecosystems-a review. Mitigation and Adaptation Strategies for Global Change 11 (2006) 403-427. https://doi.org/10.1007/s11027-005-9006-5

[28] M. Zainab, A. El Hanandeh, Q. J. Yu, Date Palm (Phoenix Dactylifera L.) Seed Characterization for Biochar Preparation, Journal of Analytical and Applied Pyrolysis 115 (2015) 392-400. https://doi.org/10.32738/ceppm.201509.0015

[29] H.L. Mudoga, H. Yucel, \& N.S.Kincal, Decolorization of sugar syrups using commercial and sugar beet pulp based activated carbons. Bioresource Technology, 99-9 (2008) 3528-3533. https://doi.org/10.1016/j.biortech.2007.07.058

[30] C.A. Black, O.D. Evans ; L.E.Ensminger, J.L. White. F.E. Clark, R.C. Dinaver, Methods of Soil Analysis part II, Chemical and Microbiological properties, 2nd, Soil Sci., socities of Am. Inc., publications Madison Wisconsin, USA (1982)1573.

[31] A.O. Rolf, L.R. Bakken, Viability of soil bacteria: optimization of plate counting technique and comparison between total counts and plate counts within different size groups. Micro. Ecol. 13 (1987) 59-74. https://doi.org/10.1007/bf02014963

[32] Difco manual, Dehydrated culture media and reagents for microbiology, laboratories incorporated, Detroite, Mitchigan, 48232, USA, (1985) 621.

[33] N. Claoston, A.W. Samsuri, M.H. Ahmad Husni, M.S. Mohd Amran, Effects of pyrolysis temperature on the physicochemical properties of empty fruit bunch and rice husk biochars, Waste Manag Res, 32-4 (2014) 331-339. https://doi.org/10.1177/0734242x14525822

[34] J. Lehmann, M.C. Rillig, J. Thies, C.A. Masiello, W.C. Hockaday, D. Crowley, Biochar effects on soil biota - A review. Soil Biology and Biochemistry, $43-9$ (2011) 1812-1836.

Retrieved October 11, 2013. https://doi.org/10.1016/j.soilbio.2011.04.022

[35] M.K. Hossain, V. Strezov, K.Y. Chan, P.F. Nelson, Agronomic properties of wastewater sludge biochar and bioavailability of metals in production of cherry tomato (Lycopersicon 
esculentum), Chemosphere, 789 (2010) 1167-1171.

https://doi.org/10.1016/j.chemosphere.2010.01.009

[36] M. Inyang, B. Gao, P. Pullammanappallil, W. Ding, A.R. Zimmerman, Biochar from anaerobically digested sugarcane bagasse. Bioresour Technol, 101-22 (2010) 8868-8872. https://doi.org/10.1016/j.biortech.2010.06.088

[37] S. Kloss, F. Zehetner, A. Dellantonio, R. Hamid, F. Ottner,V. Liedtke, G. Soja, Characterization of slow pyrolysis biochars: effects of feedstocks and pyrolysis temperature on biochar properties, J Environ Qual, doi: 10.2134/jeq2011.0070, 41-4 (2012) 990-1000. https://doi.org/10.2134/jeq2011.0070

[38] J. Yuan, R. Xu, \& H. Zhang, The forms of alkalis in the biochar produced from crop residues at different temperatures. Bioresource Technology, doi:10.1016/j.biortech.2010.11.018, 102-3 (2010) 3488-3497. https://doi.org/10.1016/j.biortech.2010.11.018

[39] D. M. Glazonova. P.A. kuryntseva, S.Y. Selvenovskaya P.Y. Galytskaya, Assessing the potential of using biochar as a soil conditioner. IOP conf. series: earth and Environmental sci., (2018) 107 (012059). https://doi.org/10.1088/1755-1315/107/1/012059

[40] R.A. Adel , A. Usmana, M.V. Abduljabbarc, Y.S. Oke,M. Ahmada, M. Ahmada, J.Elfakia, S.S. Abdulazeema, M. I. Al-Wabela, Biochar production from date palm waste: Charring temperature induced changes in composition and surface chemistry, 2015.

[41] H.A. Qasim, A.l. M. Rahman, M. H. Salman, Z. H. Aly, A.K. Abdul Satar, A. Sh., J. Abdul Ameer, Characterization of Biochar Produced from IRAQI Palm Fronds by Thermal Pyrolysis Al-Khwarizmi Engineering Journal 11-2 (2015) 92-102.

[42] E.B. Katy, K. R. Brye, Mary C. Savin, D.M. Longer, Biochar Source and Application Rate Effects on Soil Water Retention determined Using Wetting Curves, Open Journal of Soil Science, 5 (2015) 1-10. https://doi.org/10.4236/ojss.2015.51001 